\title{
Fallopian Tube Cancer TNM Finding v7
}

National Cancer Institute

\section{Source}

National Cancer Institute. Fallopian Tube Cancer TNM Finding v7. NCI Thesaurus. Code C89664.

A finding about one or more characteristics of fallopian tube cancer, following the rules of the TNM AJCC V7 classification system. Histologic confirmation of primary disease with complete evaluation of the abdomen and pelvis is required. (from AJCC 7th Ed.) 